\title{
Escapology, or How to Escape Malthusian Traps
}

\author{
Jörg Friedrichs, University of Oxford
}

Forthcoming in John Brewer, Neil Fromer, Fredrik Albritton Johnson, and Frank Trentmann (eds)

Scales of Scarcity in the Modern World, 1800-2075, London: Bloomsbury

\begin{abstract}
This chapter discusses ways of escaping Malthusian traps, showing how a framework taking the classical problem of overpopulation as its heuristic starting point can provide a key to contemporary problems and ways of dealing with them. Based on a concise model of the overpopulation trap, I discuss a variety of escape routes starting with the solutions and non-solutions suggested by Malthus (moral restraint, vice, and misery); followed by strategies of shifting the problem to subalterns and/or outsiders; and culminating in cornucopian solutions like exponential industrial growth and technical progress. Subsequently, I move to the neo-Malthusian challenges of the contemporary era, from climate change to energy scarcity. After a brief outline of the traps threatening the foundations of contemporary industrial civilization, I survey conceivable ways of dealing with them. In doing so, I revisit the escape routes discussed previously and ponder which of them, if any, may be available, eventually in a modified form, to deal with looming scenarios of neo-Malthusian crisis.
\end{abstract}

\section{Bio-note}

Jörg Friedrichs is Associate Professor in Politics at the University of Oxford, at the Department of International Development and St Cross College. His theoretical interests are concentrated in the fields of international relations and political sociology. He takes a broad transdisciplinary approach to research. He is the author of a new intercultural theory of international relations (International Theory 1/2016). Among many other publications, he has authored a book entitled The Future is Not What It Used to Be: Climate Change and Energy Scarcity (MIT Press, 2013).

\section{Acknowledgments}

The author is grateful to Einar Wigen and Iver Neumann, as well as the editors and other contributors to this volume, for critical comments and helpful suggestions.

\section{Contact details}

Dr. Jörg Friedrichs, Associate Professor in Politics, Department of International Development, Queen Elizabeth House, 3 Mansfield Road, Oxford OX1 3TB. joerg.friedrichs@qeh.ox.ac.uk 


\section{Introduction}

Thomas Malthus has a bad press, but undeservedly so. Many problems of the contemporary era have a structure that is similar to the Malthusian problem of overpopulation. Hence, a Malthusian framework seems promising. The basic logic is simple enough: one function grows so fast that it exceeds the limits posed by another function, with overshoot leading to dire consequences.

For Malthus, the first function was population. In his view, population was growing faster than the second function - food production. The result was a particular form of scarcity, namely food scarcity triggered by overpopulation and leading to "vice and misery". Today, parallel cases abound. For example, environmental impact or greenhouse gas emissions (first function) may exceed the Earth's regenerative capacity or the capacity of the climate system to absorb greenhouse gases (second function). The consequence of overshoot may be environmental havoc or catastrophic climate change. The effects may turn out dreadful enough to deserve the epithet "Malthusian."

Malthus gave us helpful clues on how to think about the logical structure of such problems, but his thought on how to escape them (his "escapology") is far less developed. This is a shortcoming in his otherwise highly articulate thought, but it is no excuse for abandoning his framework. Instead, it is simply an invitation to think harder. Unpleasant as it may be to contemplate Malthusian and neoMalthusian traps, we will do well to think harder about possible ways of escaping them.

This chapter discusses ways of escaping Malthusian traps, showing how a framework taking the classical problem of overpopulation as its heuristic starting point can provide a key to contemporary problems and ways of dealing with them. Based on a concise model of the overpopulation trap, I discuss a variety of escape routes starting with the solutions and non-solutions suggested by Malthus (moral restraint, vice, and misery); followed by strategies of shifting the problem to subalterns and/or outsiders; and culminating in cornucopian solutions like exponential industrial growth and technical progress. Subsequently, I move to the neo-Malthusian challenges of the contemporary era, from climate change to energy scarcity. ${ }^{1}$ After a brief outline of the traps threatening the foundations of contemporary industrial civilization, I survey conceivable ways of dealing with them. In doing so, I revisit the escape routes discussed previously and ponder which of them, if any, may be available, eventually in a modified form, to deal with looming scenarios of neo-Malthusian crisis.

\section{The Malthusian trap}

Thomas Malthus' Essay on the Principle of Population (1798) has an oft-quoted statement that neatly summarizes his theory: "Population, when unchecked, increases in a geometrical ratio. Subsistence increases only in an arithmetical ratio." ${ }^{2}$ The basic idea is that population grows exponentially, but the growth of a society's means of subsistence is only linear. Linear growth in food supply cannot make up for the skyrocketing needs of an exponentially growing population. Conversely, exponential growth of population outpaces the linear increase of subsistence. As population grows

\footnotetext{
${ }^{1}$ See Jörg Friedrichs, The Future Is Not What It Used to Be: Climate Change and Energy Scarcity (Cambridge, MA: MIT Press, 2013).

${ }^{2}$ Thomas Malthus, An Essay on the Principle of Population, as it affects the future improvement of society (London: J. Johnson, 1798), 14.
} 
faster than subsistence, food intake per capita shrinks inexorably. At some point, population growth runs against the hard limit posed by minimum food intake per capita-with tragic results.

Malthus was aware that population can temporarily exceed its long-term limits. For example, there can be good harvests for twenty or thirty years. In that case, population levels may exceed the longterm subsistence base. Malthus cautioned, however, that this can happen only for so long. The longer such overshoot lasts, the greater the overpopulation. With growing overpopulation, the famine bound to occur after a bad harvest will then be even more devastating. If the famine is not sufficient to decimate population to a viable level, then other calamities such as war and pandemics may do so. A combination of famine, war, pandemics, and deviant behaviour ("vice and misery") will decimate population to a level consistent with the means of subsistence, until the cycle starts anew.

So much for the basic Malthusian model of overpopulation. I can be brief because I have described it elsewhere. ${ }^{3}$ During his lifetime, Malthus re-proposed his theory several times: first in the two-volume version of the Essay of 1803 and then in further iterations, with the last edition appearing in 1826. ${ }^{4}$ These modifications need not detain us here, as they left the model intact. What matters, for the present purpose, is only the model itself in its axiomatic elegance (Figure 1).

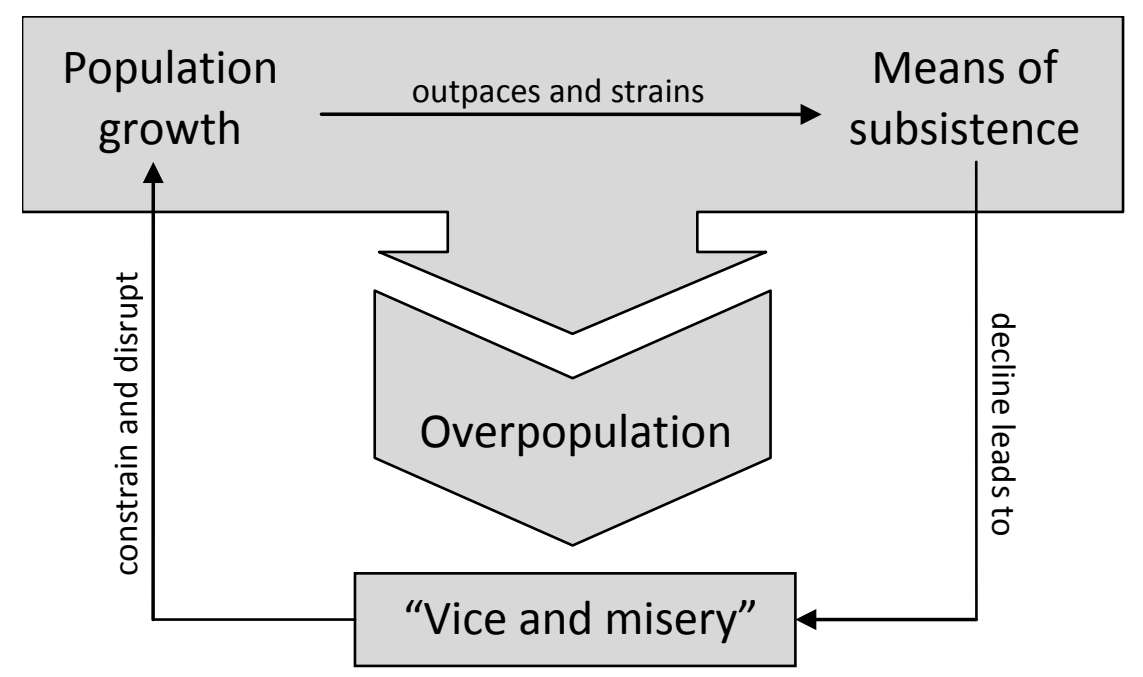

Figure 1: The Malthusian trap ${ }^{5}$

\section{Escape routes from the Malthusian trap}

Logically speaking, the solution to the Malthusian problem is closing the gap between exponential growth in population and linear growth in subsistence. This can happen either through "vice and misery" or through a managed solution. One way of achieving a managed solution is to constrain

\footnotetext{
${ }^{3}$ Jörg Friedrichs, "Who's afraid of Thomas Malthus?," in Understanding Society and Natural Resources: Forging New Strands of Integration Across the Social Sciences, ed. Michael J. Manfredo, et al. (New York: Springer, 2014), 67-92, at 68-70. The chapter is available online through open access.

${ }^{4}$ Thomas Malthus, An Essay on the Principle of Population; or, A view of its past and present effects on human happiness (London: John Murray, 1826); cf. Donald Winch, Malthus (Oxford: Oxford University Press, 1987).

${ }^{5}$ Reproduced from Friedrichs, "Who's afraid of Thomas Malthus?," 70.
} 
population growth. Another way is exponential growth in the means of subsistence. Malthus called for the former and discarded the latter, but modernity has shown that it is possible, at least temporarily, to increase agricultural yields at a pace exceeding population growth. As it seems, however, most of history has neither followed classical Malthusian nor modern cornucopian patterns. Instead, the most common way of dealing with the problem of overpopulation has been to shift the problem to subalterns and/or outsiders. Let us discuss all of these escape routes in turn.

\section{Moral restraint, vice, and misery}

Malthus himself contemplated one solution and two non-solutions to the overpopulation trap. His preferred solution was "moral restraint," or the voluntary renouncement of procreation in a religiously correct and morally virtuous manner. He contrasted this with "vice," or objectionable forms of non-reproductive sex. Failing population control, Malthus argued, the consequences are dire, leading to "misery," or social calamities such as famine and war decimating the population.

By moral restraint, Malthus intended the control of reproductive behaviour in ways acceptable to him as a Protestant Christian. Married couples should engage in sexual moderation to curtail the number of their offspring, and non-married people should renounce sexual intercourse altogether. As an Anglican country curate and moralist, Malthus had a visceral dislike for "vice", which included any form of controlling reproduction by means other than moral restraint. To him, social institutions such as prostitution and infanticide were immoral and hence unacceptable.

But was it realistic to expect people to control their reproductive instinct? Malthus had doubts about that. Tragically, "misery" remained the most likely way for the system to return to equilibrium. For religious and humanitarian reasons, however, Malthus could not embrace misery because it relied on tragedy to run its course. He detested destructive forms of population decimation such as warfare, genocide, famine, pandemics, and other calamities. By labelling the alternatives pejoratively as "vice and misery", Malthus made clear that for him moral restraint was the only acceptable option.

\section{Depredation of subalterns}

In restricting conceivable escape routes to moral restraint, vice, and misery, Malthus overlooked the fact that humans have a habit of shifting problems that they cannot solve to their fellow humans. In the course of history, humans have developed two additional ways of escaping the Malthusian trap by shifting the burden to others: the depredation of subalterns and the depredation of outsiders.

Let us begin with the depredation of subalterns. One of the most popular objections to Malthusian theory is that equality might somehow solve the problem of overpopulation and poverty. Critics claim that there is enough for all to go round if only food were distributed more evenly. Historically, the opposite seems to be the case. Inequality has been a solution to the Malthusian problem!

The history of institutionalized inequality started in a seemingly innocuous way, with affluent and hence "complex" hunter-gatherer communities relying on the collection, storage, and redistribution of surplus food. The strategy was for the community to store food as an insurance against famine 
and thus to create a social buffer against food insecurity. ${ }^{6}$ Most typically, the people specializing in storage and the provision of other public goods would be "big men" or priests, acting on behalf of commoners. In hunter-gatherer and other so-called primitive societies, those controlling food stocks were compelled to meet the expectations of their fellow tribespeople lest the latter would walk away or revolt against their leadership. ${ }^{7}$ Originally, this conditional form of inequality amounted to a social bargain that benefitted both sides. From a Malthusian perspective, it created a suitable buffer to protect the community as a whole if not from vice then at least from misery.

Inequality became institutionalized, or structural, when, with the Neolithic or agricultural revolution, property of land became private and privilege became hereditary, with more and more people extracting rents from other people rather than resources from nature. ${ }^{8}$ Primitive accumulation enabled the upper echelons of "civilized" societies-warriors and priests, bureaucrats and merchantsto amass capital, lock in privilege, and thereby exempt themselves from the Malthusian trap.

To some degree, the elites kept using the resources extracted from the community to produce public goods. They bolstered their legitimacy and served their societies by engaging in activities such as investment in irrigation systems or the distribution of food rations during famine. Increasingly, however, they would have kept a handsome portion of the surplus for themselves. In extremis, this allowed them to ensure their own survival over and above the commoners. Chances of survival were stacked in favour of the elites by the fact that many of them had specialized in coercion. ${ }^{9}$ Short of an invasion or mutiny, the elites had thus ensured themselves against the Malthusian trap. ${ }^{10}$

Agent-based modelling confirms that the emergence of inequality went hand in hand with Malthusian population dynamics. ${ }^{11}$ Originally this worked best in those areas were agriculture relied on grain, which was easy to appropriate. ${ }^{12}$ Since the beginnings of agriculture, the mechanisms have become more intricate, owing to higher levels of social differentiation and stratification. What is more, the exemptions from the Malthusian trap have come to extend far beyond the initial classes of warriors and priests, bureaucrats and merchants. Nevertheless, even in the contemporary era, famines arise in situations where food remains available in sufficient quantity to some but not others (far from refuting Malthusian theory, this is a result of problem shifting as outlined in this section). ${ }^{13}$

\footnotetext{
${ }^{6}$ Alain Testart, "The significance of food storage among hunter-gatherers: residence patterns, population densities, and social inequalities," Current Anthropology 23, no. 5 (1982): 523-537.

${ }^{7}$ Marshall Sahlins, "Poor man, rich man, big-man, chief: political types in Melanesia and Polynesia," Comparative Studies in Society and History 5, no. 3 (1963): 285-303.

${ }^{8}$ Douglass C. North and Robert Paul Thomas, "The first economic revolution," Economic History Review 30, no. 2 (1977): 229-241; Mary K. Shenk et al., "Intergenerational wealth transmission among agriculturalists: foundations of agrarian inequality," Current Anthropology 51, no. 3 (2010): 65-83.

${ }^{9}$ This is not to say that war and violence started with agricultural civilization. See Lawrence H. Keeley, War before Civilization: The Myth of the Peaceful Savage (New York: Oxford University Press, 1996); Steven A. LeBlanc, Constant Battles: The Myth of the Peaceful, Noble Savage (New York: St. Martin's Press, 2003). ${ }^{10}$ Serge Svizzero and Clement Tisdell, "Inequality and wealth creation in ancient history: Malthus' theory reconsidered," Economics \& Sociology 7, no. 3 (2014): 222-239.

${ }^{11}$ Simon T. Powers and Laurent Lehmann, "An evolutionary model explaining the Neolithic transition from egalitarianism to leadership and despotism," Proceedings of the Royal Society B 281, no. 20141349 (2014). 12 Joram Mayshar et al., "Cereals, Appropriability and Hierarchy. Barcelona GSE Working Paper No. 842," (2015).

${ }^{13}$ Amartya Sen, Poverty and Famines: An Essay on Entitlement and Deprivation (Oxford: Clarendon, 1981).
} 
The bottom line is that structural inequality serves, at least in part, as a social buffer, or insurance policy, against the Malthusian trap. Elites seek privilege for many other reasons including sheer advantage, but inequality lies hidden in plain sight as a way to deal with the Malthusian problem.

\section{Depredation of outsiders}

Having discussed the depredation of subalterns, let us move to the depredation of outsiders. The paradigmatic case is pastoral nomadism. Let me exemplify this by the evolution of nomadism on the Eurasian steppe, a model that may also apply to nomadic pastoralists in other world regions. ${ }^{14}$

The origin of pastoral nomadism remains debated. ${ }^{15}$ Regardless of the details, it must have occurred after the agricultural revolution when, due to decisive technological advances in farming, herding became an increasingly differentiated and spatially segregated activity. ${ }^{16}$ Nomadic pastoralism may have emerged in Mesopotamia when settled agriculture became too intensive to allow for the presence of large herds on fertile lands, with segments of the population moving away from farming centres and specializing in animal husbandry. ${ }^{17}$ Herdsmen migrated to marginal areas that were unsuitable for farming and became pastoral nomads. In the wilderness, pastoral populations were constrained by the number of their livestock, which in turn was constrained by how many animals their land base could support. ${ }^{18}$ Their lifestyle allowed for a level of social complexity and organization that was impressive in and of itself, but could hardly rival the sedentary societies developing around the same time. ${ }^{19}$ Importantly, however, pastoral nomadism awarded distinct military advantages. Horses were available in large numbers, and the entire tribe was mobile so that, in a military campaign, it was not necessary to leave behind a garrison to protect cattle and kin. ${ }^{20}$

This is where the depredation of outsiders comes into play. As the ancient Greek historiographer Herodotus noted about the Scythians: "Since they have no towns or strongholds, but carry their homes around with them on wagons, since they are all expert on using their bows from horseback, and since they depend on cattle for food rather than on cultivated land, how could they fail to be invincible and elusive?" 21 Owing to military prowess and supplemented by trade, including the taxation of caravans traversing the Silk Road, the depredation of outsiders enabled levels of social complexity and material wealth that the steppe would otherwise not have supported.

\footnotetext{
${ }^{14}$ David W. Anthony, The Horse, the Wheel, and Language: How Bronze-Age Riders from the Eurasian Steppes Shaped the Modern World (Princeton, NJ: Princeton University Press, 2007); Christopher I. Beckwith, Empires of the Silk Road: A History of Central Eurasia from the Bronze Age to the Present (Princeton, NJ: Princeton University Press, 2009); Iver B. Neumann and Einar Wigen, The Steppe Tradition and Eurasian State Building, 4000 BCE-2017 CE (Cambridge: Cambridge University Press, forthcoming).

${ }^{15}$ Anatoly M. Khazanov, Nomads and the Outside World, 2nd ed. (Madison: University of Wisconsin Press, 1994), Chapter 2.

${ }^{16}$ Andrew Sherratt, "Plough and pastoralism: aspects of the secondary products revolution," in Pattern of the Past: Studies in Honour of David Clarke, ed. Ian Hodder, Isaac Glynn, and Norman Hammond (Cambridge: Cambridge University Press, 1981), 261-305.

${ }^{17}$ Susan H. Lees and Daniel G. Bates, "The origins of specialized nomadic pastoralism: a systemic model," American Antiquity 39, no. 2 (1974): 187-193.

18 Neil Roberts, The Holocene: An Environmental History, 3rd ed. (Chichester: Wiley-Blackwell, 2014), $241-242$.

${ }^{19}$ William Honeychurch, "Alternative complexities: the archaeology of pastoral nomadic states," Journal of Archaeological Research 22, no. 4 (2014): 277-326.

${ }^{20}$ Neumann and Wigen, The Steppe Tradition and Eurasian State Building, Chapter 2.

${ }^{21}$ Herodotus, The Histories. Translated by Robin Waterfield (Oxford: Oxford University Press, 1998), IV:46.
} 
One of the consequences of this predatory strategy was a revised social bargain among nomads. Whereas previously nomadic leaders offered a stock of spare animals in exchange for the loyalty of their followers, now they offered access to wealth from neighbours to those willing to submit to their leadership so that, united, the nomads would become a formidable force. Well-organized nomadic hordes were able to raid their sedentary neighbours and extract tribute from them, as happened when the Scythians started looting Mesopotamia in the 7th century BC.

A few centuries later and further to the East, Central Asian tribes began a succession of at least fifteen nomadic empires and supra-tribal federations raiding China, starting with the Xiongnu around 200 BC; including two Turkic empires between 550 and 750 AD; culminating in the Mongol empires, ca. 1200-1350; and ending with the final defeat and extermination of the Zunghars around $1750 .{ }^{22} \mathrm{It}$ is possible to see the interaction between China and its nomadic steppe neighbours as a case of competitive cultural coevolution, with the nomads preying on their sedentary neighbours. ${ }^{23}$

On the one hand, nomadic populations were constrained by their land base. On the other hand, they could supplement their subsistence base with agricultural products and luxuries acquired from neighbours through raiding, trading, and the extortion of tribute. In combination, raiding, trading, and tribute worked as an effective insurance against the Malthusian trap of overpopulation.

\section{Depredation of subaltern outsiders}

While it is possible to contemplate the depredation of subalterns and outsiders separately, they tend to occur in combination. Some societies predominantly rely on one form of depredation only, but the historical norm is the depredation of people who are both subalterns and outsiders.

Steppe nomads, for example, moved from the depredation of subalterns to the depredation of outsiders, and then further to the depredation of subaltern outsiders. Initially, pastoral nomadism relied less on the depredation of outsiders than on inequality among nomads. ${ }^{24} \mathrm{As}$ in the case of advanced foragers and agricultural societies, this started as an insurance against Malthusian misery. Where foragers and agricultural societies relied on storage, nomads relied on clan leaders holding a stock of surplus cattle that they would borrow their followers during and after a famine. Inequality had advantages for both sides, although the elites must have benefitted more. Commoners benefitted from the fact that leaders would vouch for their survival in times of hardship, providing emergency aid and restocking their herds. ${ }^{25}$ Leaders and their clans benefitted even more: their lifestyle was lavish, and they were the last to starve. Structural inequality was ensconced in the social bargain between nomad leaders and their followers, and contributed to solving the Malthusian problem. ${ }^{26}$

\footnotetext{
22 J. Daniel Rogers, "Inner Asian states and empires: theories and synthesis," Journal of Archaeological Research 20, no. 3 (2012): 205-256.

${ }^{23}$ Thomas J. Barfield, The Perilous Frontier: Nomadic Empires and China (Cambridge, MA: Blackwell, 1989). See also Nicola Di Cosmo, Ancient China and its Enemies: The Rise of Nomadic Power in East Asian History (Cambridge: Cambridge University Press, 2002).

${ }^{24}$ Small hordes of herders exhibit similar material inequalities as small-scale agricultural societies. See Monique Borgerhoff Mulder et al., "Intergenerational wealth transmission and the dynamics of inequality in small-scale societies," Science 326 (2009): 682-688.

${ }^{25}$ Anthony, The Horse, the Wheel, and Language, 154-155.

${ }^{26}$ Foragers, farmers, herders - structural inequality originates in the provision of storage as a public good.
} 
As societies grew larger, sedentary civilizations became more hierarchical whereas nomadic societies remained rather egalitarian. The reason was that herders could walk away and move to another part of the steppe when they felt their leaders were asking too much. Hence, even tribal leaders were mostly compelled to pursue a pastoral way of life rather than becoming rentiers, as was common in agricultural societies. This was disappointing for ambitious upstarts. What could an aspiring tribal leader do to obtain more resources and a more exalted status? He could raid outsiders, and preferably sedentary outsiders who had accumulated wealth and were easy to locate. Thanks to the depredation of outsiders, sedentary or otherwise, tribal leaders and their entourage were able to elevate themselves to a status that nomadic egalitarianism would otherwise not have supported. ${ }^{27}$

Territorial conquest took the arrangement to the next level. Given their military strength, nomads were in a position to spin off excess populations who would leave the steppe and become conquerors. The nomadic conquerors would then not only extract resources from the vanquished but also become their political overlords. In other words, they would move to the depredation of subaltern outsiders. China under Kublai Khan and Persia under Tamerlane are cases in point. ${ }^{28}$

This stands for a more general pattern prevailing in cases of conquest. If it is true that the Aryans managed to establish themselves as upper castes after their invasion of India many thousand years ago, then this must have protected their descendants from starvation and other Malthusian calamities while at the same time increasing the plight of the lower castes. The same seems to apply for great migrations, whenever an invader population subdues an indigenous population. Similarly, classical empires from China to Rome and colonial empires from the Portuguese to the British have relied on military superiority to impose themselves on, and extract resources from, the populations brought under their control. The depredation of subaltern outsiders is the historical norm.

It bears emphasis that both the depredation of subalterns and of outsiders, as well as any combinations of the two, are particularistic solutions. They do not solve the Malthusian problem as such but shift it from certain individuals or groups to others. For example, the ability of elites in agricultural societies to extract resources from commoners insured them against the risk of starvation during a famine. Commoners, by contrast, could not count on the same level of food security. Similarly, the ability of nomads to loot resources from sedentary populations improved their own food security while aggravating the food insecurity of the sedentary populations, especially during a period of drought and famine. Hybrid solutions, such as empire-building and colonialism, where those depredated are both subalterns and outsiders at the same time, similarly shift the burden from the wellto-do to those less fortunate, rather than addressing the Malthusian problem as such.

\section{Cornucopian solutions}

Malthus thought the only way to close the gap between exponential growth of population and linear growth of subsistence was to curb population. Industrial modernity has shown that it is also possible, at least temporarily, to close the gap by exponential growth in subsistence. The last two centuries have seen extended periods of exponential economic growth outpacing population growth and enabling a handsome increase in per-capita wealth, defying Malthusian expectations.

\footnotetext{
${ }^{27}$ Neumann and Wigen, The Steppe Tradition and Eurasian State Building, Chapter 2.

28 Ibid., Chapter 3.
} 
It is important to note, however, that this has come on the back of resource exploitation and technical progress. Thanks to cheap energy and abundant raw materials, including fossil fuels and other mineral resources, humans escaped the Malthusian trap. Enhanced resource exploitation went hand in hand with technical progress, which has greatly accelerated since the industrial revolution.

Together, resource exploitation and technical progress have enabled an unprecedented increase of human carrying capacity. World population has grown from ca. 1 billion in 1800 to 7.34 billion in 2016. Although population growth has been father than ever since the agricultural revolution, industrial society has temporarily abrogated the Malthusian trap of overpopulation. ${ }^{29}$ The "green revolution" of the 1970s has defused the "population bomb" 30 for another two generations. Serial doublings of the economy, including enhanced agricultural yields, have produced the cornucopian notion that abundance is the norm and scarcity an unacceptable aberration and deviation from it. ${ }^{31}$

The mobility of people, goods, and capital has further contributed to this happy state. In previous centuries, migration to "underpopulated" landmasses such as America and the import of raw materials and foodstuffs from colonies mitigated the Malthusian problem for Europeans, typically at the expense of indigenous populations (depredation of subaltern outsiders). While migration remains attractive, there are hardly any underpopulated landmasses left and migrants now mostly move in reverse direction, from the Global South to advanced industrial countries. International trade and the allocation of capital to where it bears the highest yields also enhances global carrying capacity, although it stands to reason that at some point globalization is bound to level off.

Due to the so-called demographic transition, world population is slowly moving away from patterns of exponential growth. Nevertheless, it is still on track to growing by more than half, from around 7.3 billion in 2013 to about 9.7 billion in 2050 and 11.2 billion in $2100 .{ }^{32}$ Although fertility is now at or below replacement level in most parts of the world, the populations of most countries will continue to grow for a very long time due to so-called demographic momentum..$^{33}$ Even so, the world population is showing signs of moving towards a plateau over the coming century.

At first sight, this amounts to an impressive battery of cornucopian escape routes from the Malthusian trap: resource extraction and technical progress; globalization; and the demographic transition. Alas, most of these putative escape routes are temporary rather than permanent. Resources are limited, and technical innovation may stall. ${ }^{34}$ Infinite growth on a finite planet is impossible. Globalization may level off or even disintegrate. The demographic transition may not withstand an epochal reversal of economic growth and a decline of modern accomplishments such as the education of women. If we imagine the demise of industrial society and related blessings, then most countries of today's world are hopelessly overpopulated. Malthus may turn out to be right after all.

The industrial era has created a "fool's paradise" of sorts that temporarily abrogates the worst aspects of Malthusian tragedy. Once industrial civilization enters a terminal decline, the Malthusian

\footnotetext{
${ }^{29}$ Antony Trewavas, "Malthus foiled again and again," Nature 418 (2002): 668-670.

30 Paul R. Ehrlich, The Population Bomb (New York: Ballantine Books, 1968).

${ }^{31} \mathrm{H}$. Charles J. Godfray et al., "Food security: the challenge of feeding 9 billion people," Science 327 (2010): $812-818$

32 UN, World Population Prospects: The 2015 Revision (New York: United Nations, 2015).

${ }^{33}$ Wolfgang Lutz and K.C. Samir, "Dimensions of global population projections: what do we know about future population trends and structures?," Philosophical Transactions of the Royal Society B 365 (2010): 2779-2791.

34 Deborah Strumsky, José Lobo, and Joseph A. Tainter, "Complexity and the productivity of innovation," Systems Research and Behavioral Science 27, no. 5 (2010): 496-509.
} 
problem of overpopulation may yet come to haunt humanity. To make a bad situation worse, the challenge is not just overpopulation but also a host of additional neo-Malthusian traps.

\section{Neo-Malthusian traps}

Neo-Malthusian traps are problems that have the same logical structure as the classical Malthusian trap. One function $\left(f_{1}\right)$ outpaces and strains another function $\left(f_{2}\right)$. The system has some inertia built into it, enabling temporary overshoot. Given the inexorable decline of the second function, however, overshoot leads to significant systemic disruptions, ultimately constraining the first function, and thus bringing the system back to equilibrium - but only after a devastating crisis (Figure 2). ${ }^{35}$

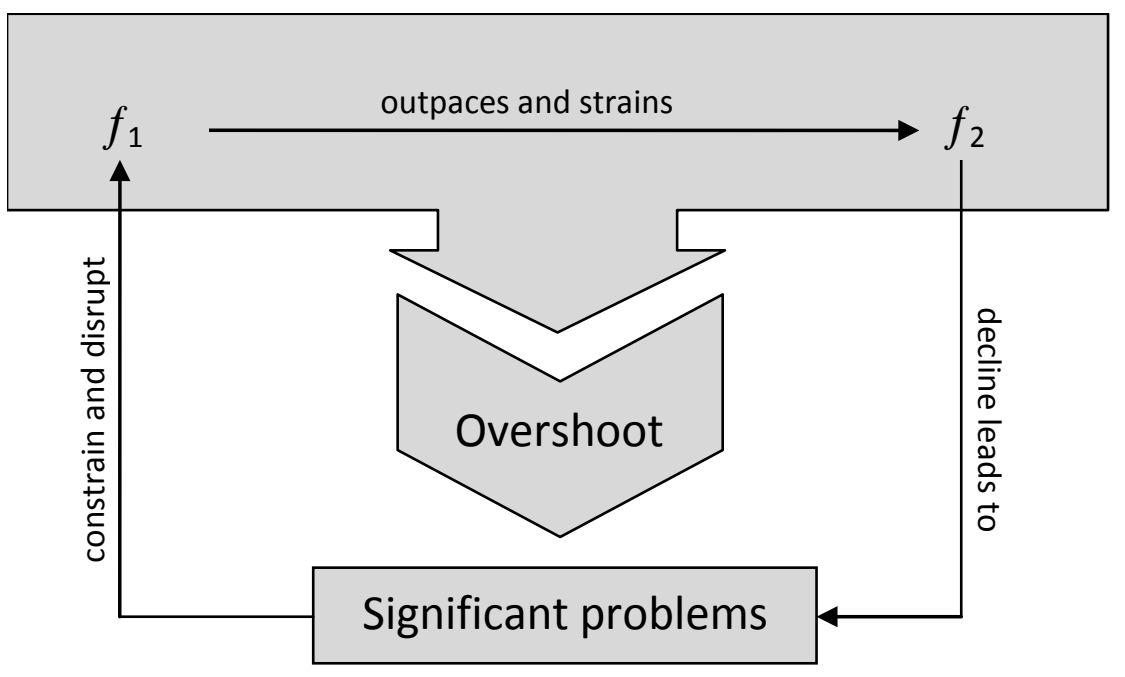

Figure 2: The logical structure of Malthusian traps ${ }^{36}$

In the classical version of the Malthusian trap, discussed in Section 2, population growth outpaces and strains the means of subsistence. Demographic inertia leads to overpopulation. Given the declining means of subsistence, overpopulation leads to what Malthus called "vice and misery," constraining and disrupting population growth and thus bringing the system back to equilibrium, but only after a dreadful period of famine, war, pestilence, moral decay, and so on.

The matrix is open to further specifications. For example, greenhouse gas emissions may overwhelm the homeostatic regulation of the climate system. Fuel depletion may lead to a decline in production capacities, leading to a situation where declining supply cannot meet rising demand. In the meantime, overshoot may occur in the form of irreversible global warming and unsustainable levels of fuel consumption. This may then lead to catastrophic climate change and energy scarcity. Ultimately, some new equilibrium is unavoidable. However, getting there may entail the demise of industrial society. The following neo-Malthusian theories follow this kind of logical template.

\footnotetext{
${ }^{35}$ This section is a condensed version of Friedrichs, "Who's afraid of Thomas Malthus?," 70-85.

${ }^{36}$ Reproduced from ibid., 71.
} 
- Environmental neo-Malthusianism. According to ecological footprint analysis, overshoot results from society's environmental impact outpacing and straining ecosystem services, leading to environmental degradation and thus undermining the Earth's regenerative capacity. ${ }^{37}$ Unless society finds a way to reduce its impact deliberately to whatever ecosystem services are able to replenish, this is bound to lead to Malthusian calamities that are difficult to fathom and will force humanity's environmental impact back to sustainable levels. ${ }^{38}$

- Climate-based neo-Malthusianism. When greenhouse gas emissions outpace the ability of the climate system to absorb them, climate change may cause serious trouble to human civilization, which appears ill-prepared for more than $2{ }^{\circ} \mathrm{C}$ of global warming. Especially when accompanied by positive reinforcements after possible tipping points, ${ }^{39}$ human misery may ultimately force a reduction of climate stresses but the climatic perturbation may last for centuries and the social and political consequences are bound to be catastrophic. ${ }^{40}$

- Energy-based neo-Malthusianism. Given the heavy dependence of industrial society on energy, fossil fuel depletion may lead to a decline, or even reversal, of economic growth. Insofar as industrial civilization needs economic growth to be sustainable, some authors argue that fossil fuel depletion may trigger the demise of prevailing social and economic models, forcing a new equilibrium at lower levels of energy throughput. It may be possible to reach such an equilibrium in the long term, but only after a long emergency. ${ }^{41}$

The neo-Malthusian theories listed thus far are deceptively simple. They provide powerful narratives, but they are insufficient for providing adequate prediction and guidance. The environment, climate system, and energy sector are more complex than suggested by such theories. Fortunately, there is no need to stop there. It is possible to develop more complex and fine-grained theories that provide higher levels of sophistication and accuracy. A survey of the literature suggests that the following more complex neo-Malthusian theories are of particular interest. ${ }^{42}$

- Limits to Growth. The seminal work by Donella Meadows and colleagues remains the most influential neo-Malthusian modelling exercise. ${ }^{43}$ Both in the original study and its updates, the authors have simulated complex interaction effects not only for food and population but also for geological resources and pollution, as well as industrial output. ${ }^{44}$

- Eco-scarcity theory. Thomas Homer-Dixon and colleagues have popularized the complex neo-Malthusian theory of eco-scarcity whereby land degradation and other environmental

\footnotetext{
${ }^{37}$ Mathis Wackernagel and William E. Rees, Our Ecological Footprint: Reducing Human Impact on Earth (Gabriola Island, BC: New Society, 1996).

${ }^{38}$ WWF, Living Planet Report 2016: Risk and Resilience in a New Era (Gland: WWF, 2016).

${ }^{39}$ Timothy M. Lenton et al., "Tipping elements in the Earth's climate system," Proceedings of the National Academy of Sciences of the USA 105, no. 6 (2008): 1786-1793.

${ }^{40}$ Naomi Oreskes and Erik M. Conway, The Collapse of Western Civilization: A View from the Future (New York: Columbia University Press, 2014).

${ }^{41}$ James Howard Kunstler, The Long Emergency: Surviving the Converging Catastrophes of the Twenty-First Century (New York: Atlantic Monthly, 2005); John Michael Greer, The Ecotechnic Future: Envisioning a PostPeak World (Gabriola Island, BC: New Society Publishers, 2009).

${ }^{42}$ For further detail, see Friedrichs, "Who's afraid of Thomas Malthus?," 77-85.

${ }^{43}$ Donella H. Meadows et al., The Limits to Growth: A Report for the Club of Rome's Project on the Predicament of Mankind (New York: Universe Books, 1972).

${ }^{44}$ Most recently, Donella H. Meadows, Jørgen Randers, and Dennis L. Meadows, Limits to Growth: The 30-Year Update (White River Junction, VT: Chelsea Green, 2004).
} 
strains combine with population pressure to cause economic busts and migratory movements, unleashing political crises and violent conflict further down the line.$^{45}$ Scholars of past climatic changes have developed similar models. For example, Zhang and colleagues have presented a model whereby climate change leads to reduced food supply per capita, triggering a complex cascade of interlocking calamities. ${ }^{46}$ Zhang et al. tested their model on historical data from the premodern and early modern era. Others have developed similar theoretical models to enable the study of present and future climate change. ${ }^{47}$

- Civilizational neo-Malthusianism. Tainter's theory of diminishing returns on complexity is another case in point. ${ }^{48}$ According to this theory, societies constantly face problems. As they devote resources to address these problems, their complexity increases. Tragically, there are diminishing returns on increasing complexity. Systemic collapse becomes almost inevitable if and when societies have depleted their reserve problem-solving capacity. ${ }^{49}$

\section{Escape routes from Neo-Malthusian traps}

Given the structural similarity between classical and neo-Malthusian traps, any possible escape routes are also likely to be structurally similar. Let us therefore revisit the escape routes from the classical Malthusian problem of overpopulation, discussed in Section 3. In doing so, let us systematically examine to what extent it is possible to adapt these escape routes and make them work for the solution of the neo-Malthusian problems beleaguering humanity in the twenty-first century.

\section{Moral restraint, vice, and misery}

As we have seen, Thomas Malthus himself considered three responses to the challenge of overpopulation: moral restraint, vice, and misery. Although the nature of the problems has changed considerably, the same classical responses are still discernible in political and academic discourse.

To begin with, the notion of moral restraint remains discernible. For example, environmentalists demand a lower ecological footprint, and environmental economists recommend a conscious strategy of economic de-growth. ${ }^{50}$ These calls lack the theological overtones found in the work of Thomas Malthus, but what else are they if not exhortations for moral restraint? Even in the classical Malthusian domain of population studies, the idea of moral restraint is still identifiable. Accepted wisdom

\footnotetext{
45 Thomas F. Homer-Dixon, Environment, Scarcity, and Violence (Princeton, NJ: Princeton University Press, 1999).

${ }^{46}$ David D. Zhang et al., "Global climate change, war, and population decline in recent human history," Proceedings of the National Academy of Sciences of the USA 104, no. 49 (2007): 19214-19219; David D. Zhang et al., "The causality analysis of climate change and large-scale human crisis," Proceedings of the National Academy of Sciences of the USA 148, no. 42 (2011): 17296-17301.

${ }^{47}$ Halvard Buhaug, Nils Petter Gleditsch, and Ole Magnus Theisen, "Implications of climate change for armed conflict," in Social Dimensions of Climate Change: Equity and Vulnerability in a Warming World, ed. Robin Mearns and Andrew Norton (Washington, DC: World Bank, 2010), 75-101.

48 Joseph A. Tainter, The Collapse of Complex Societies (Cambridge: Cambridge University Press, 1988).

49 Temis G. Taylor and Joseph A. Tainter, "The nexus of population, energy, innovation, and complexity," American Journal of Economics and Sociology 75, no. 4 (2016): 1005-1043.

50 Peter A. Victor, Managing without Growth: Slower by Design, Not Disaster (Cheltenham, UK: Edward Elgar, 2008); Tim Jackson, Prosperity without Growth: Economics for a Finite Planet (London: Earthscan, 2009); William Ophuls, Plato's Revenge: Politics in the Age of Ecology (Cambridge, MA: MIT Press, 2011).
} 
has it that the demographic transition results from an industrious work ethic where people devote more time to production and less to reproduction. Accepted wisdom has it that educated women have fewer babies. In other words, development and emancipation lead to moral restraint. ${ }^{51}$

The struggle against "vice" is also still with us, although it comes in a different guise. Fifty years ago, people like Paul Ehrlich were calling for compulsory birth control as a way to defuse the "population bomb" ${ }^{52}$ Since then, such intrusive methods have lost their legitimacy in the public imagination. Even China is abandoning its one-child policy. Tampering with the reproductive rights of women meets increasing disapproval. Similarly, calling for poor developing countries to forego industrialization in the interest of climate stability sounds vicious from a moral point of view. While different from those made by Malthus, the arguments are still moralistic. One may relate this to a broad shift of contemporary sensitivities towards liberal norms of egalitarianism and non-coercion. ${ }^{53}$

Like Malthus, pessimists emphasize that for all its desirability moral restraint seems unlikely. To them, hoping for voluntary de-growth and a deliberate reduction of the ecological footprint is seriously naive given human nature and industrial lock-in. This leads some observers back to unpleasant scenarios of Malthusian misery. Such authors claim that a sustainability transition is unavoidable, but is likely to come with serious disruptions that risk bringing out the worst of humans. ${ }^{54}$ These authors are not cynics. They agree that war, famine, pandemics and other forms of human misery are terrible scourges. Yet, in the absence of moral restraint, they may happen by default.

\section{Depredation of subalterns and outsiders}

Like misery, the depredation of subalterns and outsiders seems outrageous to contemporary sensitivities. Depredation may persist under various guises, such as the exploitation of wage labour or unequal terms of trade between industrial and developing countries, but they appear as undesirable downsides of capitalism. Unlike in past historical epochs when the depredation of subalterns and outsiders was a source of pride to those who felt "superior," they have become an embarrassment. ${ }^{55}$ Nevertheless, in practical terms they remain available as escape routes from neo-Malthusian traps for those who are unscrupulous enough to shift the problem to less fortunate people and groups.

In its original form, the depredation of subalterns rested on a sedentary (agrarian) territorial order. In times of globalization, this has changed beyond recognition. Elites have become footloose, and the subalterns depredated can be located on the other side of the globe. This may change once

\footnotetext{
${ }^{51}$ Ole Jacob Sending and Iver B. Neumann, "Governance to governmentality: analyzing NGOs, states, and power," International Studies Quarterly 50, no. 3 (2006): 651-672. Note how this feeds into a cornucopian mindset. Industrious work ethic and related moral restraint does not only reduce birth rates but also boosts investment and growth, closing the Malthusian gap between population and subsistence from both sides.

${ }^{52}$ Ehrlich, The Population Bomb.

${ }^{53}$ Ian Morris, Foragers, Farmers, and Fossil Fuels: How Human Values Evolve (Princeton, NJ: Princeton University Press, 2015).

${ }^{54}$ Kunstler, The Long Emergency; Greer, The Ecotechnic Future; Friedrichs, The Future Is Not What It Used to Be.

${ }^{55}$ Morris, Foragers, Farmers, and Fossil Fuels.
} 
again if neo-Malthusian challenges come to roost. Under such circumstances, elites may want to reterritorialize politics. It may become necessary for them to reassert their rule over discrete communities so that privileged status remains a boon in times of neo-Malthusian vice and misery.

For example, how will the rich be able to defend their luxury resorts in the face of a declining state monopoly of force and with migrants overrunning their compounds? There are two routes open to them. Some super-rich may be willing to move to a defensible position such as a Caribbean island and/or specialize in coercion by acquiring a private army, a strategy that would have to go far beyond the acquisition of bodyguards from a private security company. Others, which will include most members of the elite except for the super-rich, may not be willing or able to go down that route. They will need protection from a state-like entity enforcing law and order within a territory and determining the boundaries of the political community, i.e. who counts as a legitimate citizen or resident and who does not. The support of the well-to-do for mass migration may thus be reversed. After supporting and benefitting from globalization for generations, they may come to support not only reterritorialization but also a return to the state as a guarantor of structural inequality.

For other groups, the depredation of outsiders may offer a more promising escape route from neoMalthusian traps. Neo-nomadism is an interesting case in point. At first glance, nomadism sounds like an unlikely candidate for the solution of contemporary problems. While there are still hundreds of millions of people in Africa, the Middle East, Inner Asia, South Asia, and the Far North living a nomadic or semi-nomadic lifestyle, traditional nomadism appears to be a matter of the past. ${ }^{56}$ Partly due to climate change, classical nomadism in places like Mongolia and Oman is in decline. ${ }^{57}$ Interestingly, however, nomads can be highly adaptive to changing circumstances. ${ }^{58}$ Somalia has seen a pastoralist revival after the disintegration of the state in the late 1980s and early 1990s. Only a few years later, Mongolia saw a temporary pastoralist revival when the communist command economy collapsed and unemployment was rampant. ${ }^{59}$ Even in the early 21st Century, nomadism remains a challenge to sovereign territorial statehood and the Westphalian international order. ${ }^{60}$

While it is difficult to imagine billions of people adopting a traditional nomadic lifestyle (becoming herders), alternate forms of nomadism are already emerging and may further develop as an escape route from neo-Malthusian traps. Migrant groups are the most likely candidates for adopting neonomadism in this way. Neo-nomadism requires a willingness to move over long distances in search of resources, and a willingness to relocate when resources become scarce. Group cohesion needs to be high because only a strong allegiance to a community of fellow nomads can enable the willingness to see outsiders as a source of resource extraction rather than as fellow humans. This implies a flexible understanding of rights and property, especially those of outsiders, which in turn enables

\footnotetext{
${ }^{56}$ Anatoly M. Khazanov, "Contemporary pastoralism: old problems, new challenges," in Modern Pastoralism and Conservation: Old Problems, New Challenges, ed. Troy Sternberg and Dawn Chatty (Cambridge: White Horse Press, 2013), 5-23, at 5.

${ }^{57}$ Neil Pederson et al., "Pluvials, droughts, the Mongol Empire, and modern Mongolia," Proceedings of the National Academy of Sciences of the USA 111, no. 12 (2014): 4375-4379; Dawn Chatty and Troy Sternberg, "Climate effects on nomadic pastoralist societies," Forced Migration Review 49 (2015): 25-27.

58 Dawn Chatty, From Camel to Truck: The Bedouin in the Modern World, 2nd ed. (Cambridge: White Horse Press, 2013).

${ }^{59}$ Khazanov, "Contemporary pastoralism," 16.

${ }^{60}$ Nick McDonell, The Civilisation of Perpetual Movement: Nomadism in the Modern World (London: Hurst, 2016).
} 
neo-nomads to rely on the depredation of their sedentary host societies. Neo-nomads will depredate sedentary outsiders by default, take over when possible, and retreat when necessary.

\section{Cornucopian solutions?}

Cornucopian solutions, such as those outlined in Section 3, are temporary fixes and rest on the viability of industrial society. Alas, they appear destined to falter in times of neo-Malthusian turmoil. In any case, infinite growth on a finite planet is impossible. Some people argue that dematerialization can enable permanent exponential growth. However, a simple back-of-the-envelope calculation shows that this is not true. Let us demand that the world economy should grow for a century by 3 percent per annum, without any increase of resource consumption and pollutant emissions. By how much would it be necessary to abate the resource and emission intensity of the world economy (resources consumed and pollutants emitted per unit of GDP)? The answer: a staggering 94.8 percent. To reconcile a century of 3 percent growth with the more ambitious goal of reducing resource consumption and pollutant emissions, the abatement would have to be even more drastic. ${ }^{61}$

\section{Back to the future?}

Returning to archaic lifestyles of foraging, pastoralism, or subsistence agriculture is hardly an option for billions of people. Nevertheless, authors close to the Transition Town movement recommend horticulture as a way to achieve food security for local communities. ${ }^{62}$ In an era when industrialscale agriculture has become problematic for various social and environmental reasons, they argue, gardening and other subsistence lifestyles promise an intriguing "community solution" to those disaffected with industrial society (maybe because they have been spoilt by its blessings). ${ }^{63}$

The back-to-nature romanticism of such prescriptions appears naïve, to say the least. Under any circumstance, it is important to note that communitarianism jeopardizes liberal values. A world fragmented into local communities would hardly be amenable to maintaining a cosmopolitan outlook. ${ }^{64}$ There is strong evidence to suggest that agrarian societies, including horticultural ones, come with considerable inequality, including gender inequality. ${ }^{65} \mathrm{~A}$ crisis of industrial civilization might push some people into archaic lifestyles, but there is no reason to romanticize the "simple life." 66

\footnotetext{
${ }^{61}$ For a more extensive discussion of why infinite growth on a finite planet is impossible, see Friedrichs, The Future Is Not What It Used to Be, Chapter 1.

62 Rob Hopkins, The Transition Handbook: From Oil Dependency to Local Resilience (Totnes, UK: Green Books, 2008).

${ }^{63}$ Pat Murphy, Plan C: Community Survival Strategies for Peak Oil and Climate Change (Gabriola Island, BC: New Society Publishers, 2008); see also Olivier De Schutter, "The specter of productivism and food democracy," Wisconsin Law Review 2014, no. 2 (2014): 199-233.

${ }^{64}$ Stephen Quilley, "Degrowth is not a liberal agenda: relocalization and the limits to low energy cosmopolitanism," Environmental Values 22, no. 2 (2013): 261-286.

${ }^{65}$ Morris, Foragers, Farmers, and Fossil Fuels.

${ }^{66}$ Aggressive planetary stewardship or geoengineering might be options but I am not discussing them here because they would mark genuinely unchartered territory and may have devastating unintended consequences.
} 


\section{Conclusion}

This chapter has presented a variety of Malthusian traps and escape routes. It is important to note that not all escape routes are created equal. Not every escape route is a solution, not every solution addresses the problem, and even those solutions that do address the problem may work under some conditions but not others. Let us therefore classify the escape routes presented in this chapter on three dimensions: whether they are solutions or non-solutions; whether they address the problem or shift it elsewhere; and whether they operate in a way that is perennial or conditional.

If we apply this typology (Figure 3 ), then vice and misery fail the first criterion. They cannot count as solutions because misery is unacceptable on humanitarian, and vice on moral terms. They are undesirable consequences of a problem unsolved rather than solutions, responses, or strategies.

The depredation of subalterns and the depredation of outsiders are solutions, but they shift the problem to others rather than solving it. Worse still, the depredation of outsiders is at best a conditional way of shifting the problem because it cannot possibly work in the absence of outsiders to prey upon. ${ }^{67}$ While ethically questionable, the depredation of subalterns may count as a perennial way of shifting the problem because "the poor you always have with you" (John 12:8).

Cornucopian solutions and moral restraint address the problem directly. The problem with Cornucopian solutions is that they are conditional on the availability of resources that are exploitable in exponentially rising quantities, as well as sinks that are able to absorb the environmental fallout. Only moral restraint solves the problem in a perennial way. It will always work if (!) and when people are willing to sacrifice parochial short-term interest to collective long-term survival.

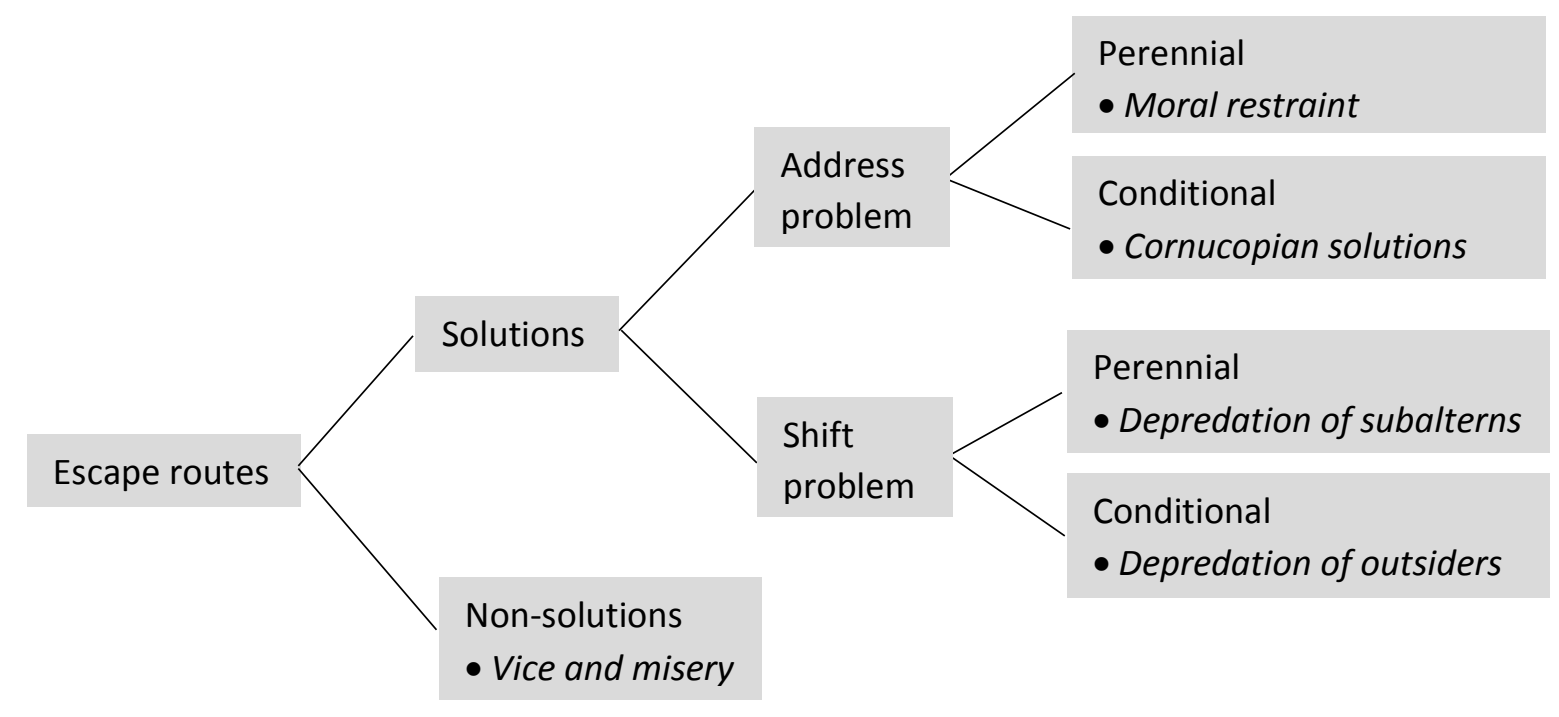

Figure 3: Escape routes from Malthusian traps

From an idealistic viewpoint, we would obviously want a solution to addresses the problem in a perennial way. Tragically, such a solution does not seem to be available short of moral restraint, which

\footnotetext{
${ }^{67}$ There is real historical evidence for this. Nomadic "shadow empires" north of China used to decline during times of imperial crisis in the Middle Kingdom. See Barfield, The Perilous Frontier. By the same token, neo-nomads will not be able to prosper without prosperous host societies.
} 
in theory can solve Malthusian problems forever and for all humankind - "imagine all the people" but remains elusive because we are in overshoot (climate change, resource depletion) and there is an entire moral economy of inaction keeping us humans parochial and short-sighted. ${ }^{68}$

${ }^{68}$ Friedrichs, The Future Is Not What It Used to Be, Chapter 6. 


\section{References}

Anthony, David W. The Horse, the Wheel, and Language: How Bronze-Age Riders from the Eurasian Steppes Shaped the Modern World. Princeton, NJ: Princeton University Press, 2007.

Barfield, Thomas J. The Perilous Frontier: Nomadic Empires and China. Cambridge, MA: Blackwell, 1989.

Beckwith, Christopher I. Empires of the Silk Road: A History of Central Eurasia from the Bronze Age to the Present. Princeton, NJ: Princeton University Press, 2009.

Borgerhoff Mulder, Monique, Samuel Bowles, Tom Hertz, Adrian Bell, Jan Beise, Greg Clark, Ila Fazzio, Michael Gurven, Kim Hill, Paul L. Hooper, William Irons, Hillard Kaplan, Donna Leonetti, Bobbi Low, Frank Marlowe, Richard McElreath, Suresh Naidu, David Nolin, Patrizio Piraino, Rob Quinlan, Eric Schniter, Rebecca Sear, Mary Shenk, Eric Alden Smith, Christopher von Rueden, and Polly Wiessner. "Intergenerational Wealth Transmission and the Dynamics of Inequality in Small-Scale Societies." Science 326 (2009): 682-688.

Buhaug, Halvard, Nils Petter Gleditsch, and Ole Magnus Theisen. "Implications of Climate Change for Armed Conflict." In Social Dimensions of Climate Change: Equity and Vulnerability in a Warming World, edited by Robin Mearns and Andrew Norton, 75-101. Washington, DC: World Bank, 2010, 75-101.

Chatty, Dawn. From Camel to Truck: The Bedouin in the Modern World. 2nd ed. Cambridge: White Horse Press, 2013.

Chatty, Dawn, and Troy Sternberg. "Climate Effects on Nomadic Pastoralist Societies." Forced Migration Review 49 (2015): 25-27.

De Schutter, Olivier. "The Specter of Productivism and Food Democracy." Wisconsin Law Review 2014, no. 2 (2014): 199-233.

Di Cosmo, Nicola. Ancient China and Its Enemies: The Rise of Nomadic Power in East Asian History. Cambridge: Cambridge University Press, 2002.

Ehrlich, Paul R. The Population Bomb. New York: Ballantine Books, 1968.

Friedrichs, Jörg. The Future Is Not What It Used to Be: Climate Change and Energy Scarcity. Cambridge, MA: MIT Press, 2013.

- - - "Who's Afraid of Thomas Malthus?" In Understanding Society and Natural Resources: Forging New Strands of Integration across the Social Sciences, edited by Michael J. Manfredo, Jerry J. Vaske, Andreas Rechkemmer and Esther A. Duke, 67-92. New York: Springer, 2014, 67-92.

Godfray, H. Charles J., John R. Beddington, Jan R. Crute, Lawrence Haddad, David Lawrence, James F. Muir, Jules Pretty, Sherman Robinson, Sandy M. Thomas, and Camilla Toulmin. "Food Security: The Challenge of Feeding 9 Billion People." Science 327 (2010): 812-818.

Greer, John Michael. The Ecotechnic Future: Envisioning a Post-Peak World. Gabriola Island, BC: New Society Publishers, 2009.

Herodotus. The Histories. Translated by Robin Waterfield. Oxford: Oxford University Press, 1998.

Homer-Dixon, Thomas F. Environment, Scarcity, and Violence. Princeton, NJ: Princeton University Press, 1999.

Honeychurch, William. "Alternative Complexities: The Archaeology of Pastoral Nomadic States." Journal of Archaeological Research 22, no. 4 (2014): 277-326.

Hopkins, Rob. The Transition Handbook: From Oil Dependency to Local Resilience. Totnes, UK: Green Books, 2008.

Jackson, Tim. Prosperity without Growth: Economics for a Finite Planet. London: Earthscan, 2009.

Keeley, Lawrence H. War before Civilization: The Myth of the Peaceful Savage. New York: Oxford University Press, 1996. 
Khazanov, Anatoly M. "Contemporary Pastoralism: Old Problems, New Challenges." In Modern Pastoralism and Conservation: Old Problems, New Challenges, edited by Troy Sternberg and Dawn Chatty, 5-23. Cambridge: White Horse Press, 2013, 5-23.

- - . Nomads and the Outside World. 2nd ed. Madison: University of Wisconsin Press, 1994.

Kunstler, James Howard. The Long Emergency: Surviving the Converging Catastrophes of the TwentyFirst Century. New York: Atlantic Monthly, 2005.

LeBlanc, Steven A. Constant Battles: The Myth of the Peaceful, Noble Savage. New York: St. Martin's Press, 2003.

Lees, Susan H., and Daniel G. Bates. "The Origins of Specialized Nomadic Pastoralism: A Systemic Model." American Antiquity 39, no. 2 (1974): 187-193.

Lenton, Timothy M., Hermann Held, Elmar Kriegler, Jim W. Hall, Wolfgang Lucht, Stefan Rahmstorf, and Hans Joachim Schellnhuber. "Tipping Elements in the Earth's Climate System."

Proceedings of the National Academy of Sciences of the USA 105, no. 6 (2008): 1786-1793.

Lutz, Wolfgang, and K.C. Samir. "Dimensions of Global Population Projections: What Do We Know About Future Population Trends and Structures?" Philosophical Transactions of the Royal Society B 365 (2010): 2779-2791.

Malthus, Thomas. An Essay on the Principle of Population, as It Affects the Future Improvement of Society. London: J. Johnson, 1798.

-- - An Essay on the Principle of Population; or, a View of Its Past and Present Effects on Human Happiness. London: John Murray, 1826.

Mayshar, Joram, Omer Moav, Zvika Neeman, and Luigi Pascali. "Cereals, Appropriability and Hierarchy. Barcelona Gse Working Paper No. 842." 2015.

McDonell, Nick. The Civilisation of Perpetual Movement: Nomadism in the Modern World. London: Hurst, 2016.

Meadows, Donella H., Dennis L. Meadows, Jørgen Randers, and William W. Behrens III. The Limits to Growth: A Report for the Club of Rome's Project on the Predicament of Mankind. New York: Universe Books, 1972.

Meadows, Donella H., Jørgen Randers, and Dennis L. Meadows. Limits to Growth: The 30-Year Update. White River Junction, VT: Chelsea Green, 2004.

Morris, lan. Foragers, Farmers, and Fossil Fuels: How Human Values Evolve. Princeton, NJ: Princeton University Press, 2015.

Murphy, Pat. Plan C: Community Survival Strategies for Peak Oil and Climate Change. Gabriola Island, BC: New Society Publishers, 2008.

Neumann, Iver B., and Einar Wigen. The Steppe Tradition and Eurasian State Building, 4000 Bce2017 Ce. Cambridge: Cambridge University Press, forthcoming.

North, Douglass C., and Robert Paul Thomas. "The First Economic Revolution." Economic History Review 30, no. 2 (1977): 229-241.

Ophuls, William. Plato's Revenge: Politics in the Age of Ecology. Cambridge, MA: MIT Press, 2011.

Oreskes, Naomi, and Erik M. Conway. The Collapse of Western Civilization: A View from the Future. New York: Columbia University Press, 2014.

Pederson, Neil, Amy E. Hessl, Nachin Baatarbileg, Kevin J. Anchukaitis, and Nicola Di Cosmo. "Pluvials, Droughts, the Mongol Empire, and Modern Mongolia." Proceedings of the National Academy of Sciences of the USA 111, no. 12 (2014): 4375-4379.

Powers, Simon T., and Laurent Lehmann. "An Evolutionary Model Explaining the Neolithic Transition from Egalitarianism to Leadership and Despotism." Proceedings of the Royal Society B 281, no. 20141349 (2014).

Quilley, Stephen. "Degrowth Is Not a Liberal Agenda: Relocalization and the Limits to Low Energy Cosmopolitanism." Environmental Values 22, no. 2 (2013): 261-286.

Roberts, Neil. The Holocene: An Environmental History. 3rd ed. Chichester: Wiley-Blackwell, 2014.

Rogers, J. Daniel. "Inner Asian States and Empires: Theories and Synthesis." Journal of Archaeological Research 20, no. 3 (2012): 205-256. 
Sahlins, Marshall. "Poor Man, Rich Man, Big-Man, Chief: Political Types in Melanesia and Polynesia." Comparative Studies in Society and History 5, no. 3 (1963): 285-303.

Sen, Amartya. Poverty and Famines: An Essay on Entitlement and Deprivation. Oxford: Clarendon, 1981.

Sending, Ole Jacob, and Iver B. Neumann. "Governance to Governmentality: Analyzing Ngos, States, and Power." International Studies Quarterly 50, no. 3 (2006): 651-672.

Shenk, Mary K., Monique Borgerhoff Mulder, Jan Beise, Gregory Clark, William Irons, Donna Leonetti, Bobbi S. Low, Samuel Bowles, Tom Hertz, Adrian Bell, and Patrizio Piraino. "Intergenerational Wealth Transmission among Agriculturalists: Foundations of Agrarian Inequality." Current Anthropology 51, no. 3 (2010): 65-83.

Sherratt, Andrew. "Plough and Pastoralism: Aspects of the Secondary Products Revolution." In Pattern of the Past: Studies in Honour of David Clarke, edited by lan Hodder, Isaac Glynn and Norman Hammond, 261-305. Cambridge: Cambridge University Press, 1981, 261-305.

Strumsky, Deborah, José Lobo, and Joseph A. Tainter. "Complexity and the Productivity of Innovation." Systems Research and Behavioral Science 27, no. 5 (2010): 496-509.

Svizzero, Serge, and Clement Tisdell. "Inequality and Wealth Creation in Ancient History: Malthus' Theory Reconsidered." Economics \& Sociology 7, no. 3 (2014): 222-239.

Tainter, Joseph A. The Collapse of Complex Societies. Cambridge: Cambridge University Press, 1988.

Taylor, Temis G., and Joseph A. Tainter. "The Nexus of Population, Energy, Innovation, and Complexity." American Journal of Economics and Sociology 75, no. 4 (2016): 1005-1043.

Testart, Alain. "The Significance of Food Storage among Hunter-Gatherers: Residence Patterns, Population Densities, and Social Inequalities." Current Anthropology 23, no. 5 (1982): 523537.

Trewavas, Antony. "Malthus Foiled Again and Again." Nature 418 (2002): 668-670.

UN. World Population Prospects: The 2015 Revision. New York: United Nations, 2015.

Victor, Peter A. Managing without Growth: Slower by Design, Not Disaster. Cheltenham, UK: Edward Elgar, 2008.

Wackernagel, Mathis, and William E. Rees. Our Ecological Footprint: Reducing Human Impact on Earth. Gabriola Island, BC: New Society, 1996.

Winch, Donald. Malthus. Oxford: Oxford University Press, 1987.

WWF. Living Planet Report 2016: Risk and Resilience in a New Era. Gland: WWF, 2016.

Zhang, David D., Peter Brecke, Harry F. Lee, Yuan-Qing He, and Jane Zhang. "Global Climate Change, War, and Population Decline in Recent Human History." Proceedings of the National Academy of Sciences of the USA 104, no. 49 (2007): 19214-19219.

Zhang, David D., Harry F. Lee, Cong Wang, Baosheng Li, Qing Pei, Jane Zhang, and Yulun An. "The Causality Analysis of Climate Change and Large-Scale Human Crisis." Proceedings of the National Academy of Sciences of the USA 148, no. 42 (2011): 17296-17301. 